\title{
Reappraisal of the Arc-Arc Collision in Taiwan
}

\author{
Tetsuzo Seno ${ }^{1, *}$ and Yoshiaki Kawanishi ${ }^{1,2}$ \\ ${ }^{1}$ Earthquake Research Institute, University of Tokyo, Tokyo 113-0032, Japan \\ ${ }^{2}$ Yoshiaki Kawanishi, NTT West Japan-Tokai, San-Nomiya, Kobe 650-0024, Japan
}

Received 8 January 2008, accepted 11 July 2008

\begin{abstract}
Although it is evident that Taiwan has been formed by the collision of the west-facing Luzon arc with the Eurasian continental margin, there remain a lot of enigmas in this collision. The major ones are: (1) a transform fault presently connecting the Manila and Ryukyu Trenches in the Philippine Sea - Eurasia relative motion direction is missing, and instead, the Ryukyu Trench extends near offshore E. Taiwan, (2) the western edge of the intermediate-depth seismicity associated with the Philippine Sea plate subduction beneath NE Taiwan has a NNW trend, not NW, and (3) a large negative Bouguer gravity anomaly, with undulation of its amplitude in a wavelength of $60-80 \mathrm{~km}$, exists along the southernmost Ryukyu forearc.

We propose a new model of the collision in Taiwan to resolve these enigmas, assuming that the southern Ryukyu forearc was migrating to the southwest with respect to Eurasia for the past several m.y. and the Luzon arc has been colliding with this actively migrating Ryukyu forearc. The northernmost Luzon arc is divided into two parts by the NNW line directing along the Philippine Sea - Ryukyu forearc motion from its initial intersection point with the Ryukyu Trench; the part west of this line has been obducted on the Ryukyu forearc-Eurasian margin, producing the collision orogen in Taiwan, and the part east of it has been subducted beneath the Ryukyu forearc.

This evolutionary scenario resolves enigmas (1) and (2) kinematically. This model also predicts that the South China Sea slab has to be torn by the westward component of the motion of the subducting Philippine Sea slab to Eurasia. This would have brought large lateral compression in the shallow portion of the Philippine Sea slab at its western border, which might lead to buckling of the slab causing the observed undulated gravity anomaly.
\end{abstract}

Key words: Taiwan, Collision, Ryukyu forearc, Philippine Sea plate, Luzon arc, Eurasian plate, Arc-polarity reversal, Obduction, Subduction

Citation: Seno, T. and Y. Kawanishi, 2009: Reappraisal of the arc-arc collision in Taiwan. Terr. Atmos. Ocean. Sci., 20, 573-585, doi: 10.3319/ TAO.2008.07.11.02(TT)

\section{INTRODUCTION}

Taiwan has been formed by the collision of the westfacing Luzon arc with the Eurasian continental margin. The uniqueness of the collision in Taiwan is that it is not a simple arc-continent collision, but is attached by subduction zones of opposite polarity (Fig. 1). Although extensive studies have been conducted so far, there remain a lot of enigmas in this collision. We first describe some of these. A transform fault connecting the southern end of the Ryukyu Trench and the northern end of the Manila Trench has been supposed by many researchers to explain this arc polarity reversal (Suppe 1981; Barrier and Angelier 1986; Teng 1990; Hsu

\footnotetext{
* Corresponding author

E-mail:seno@eri.u-tokyo.ac.jp
}

and Sibuet 1995; Sibuet and Hsu 1997; Lallemand et al. 2001; Hall 2002; Malavieille et al. 2002; Takada et al. 2007). If the submarine Manila Trench extends onshore to the deformation front at the Western Foothills (Suppe 1981; Teng 1990; Huang et al. 1992; Liu et al. 1997; Lundberg et al. 1997), a transform fault should exist from the northern end of the deformation front near Taipei to the southeast around $124^{\circ} \mathrm{E}$ of the Ryukyu Trench, striking in the relative motion direction between the Philippine Sea and Eurasian plates (N307 E, Seno et al. 1993), as depicted in Fig. 1. However, there is no feature suggesting such a transform fault offshore in the Okinawa Trough or the Ryukyu forearc. On the contrary, the negative free-air gravity anomaly associated with the Ryukyu Trench approaches 


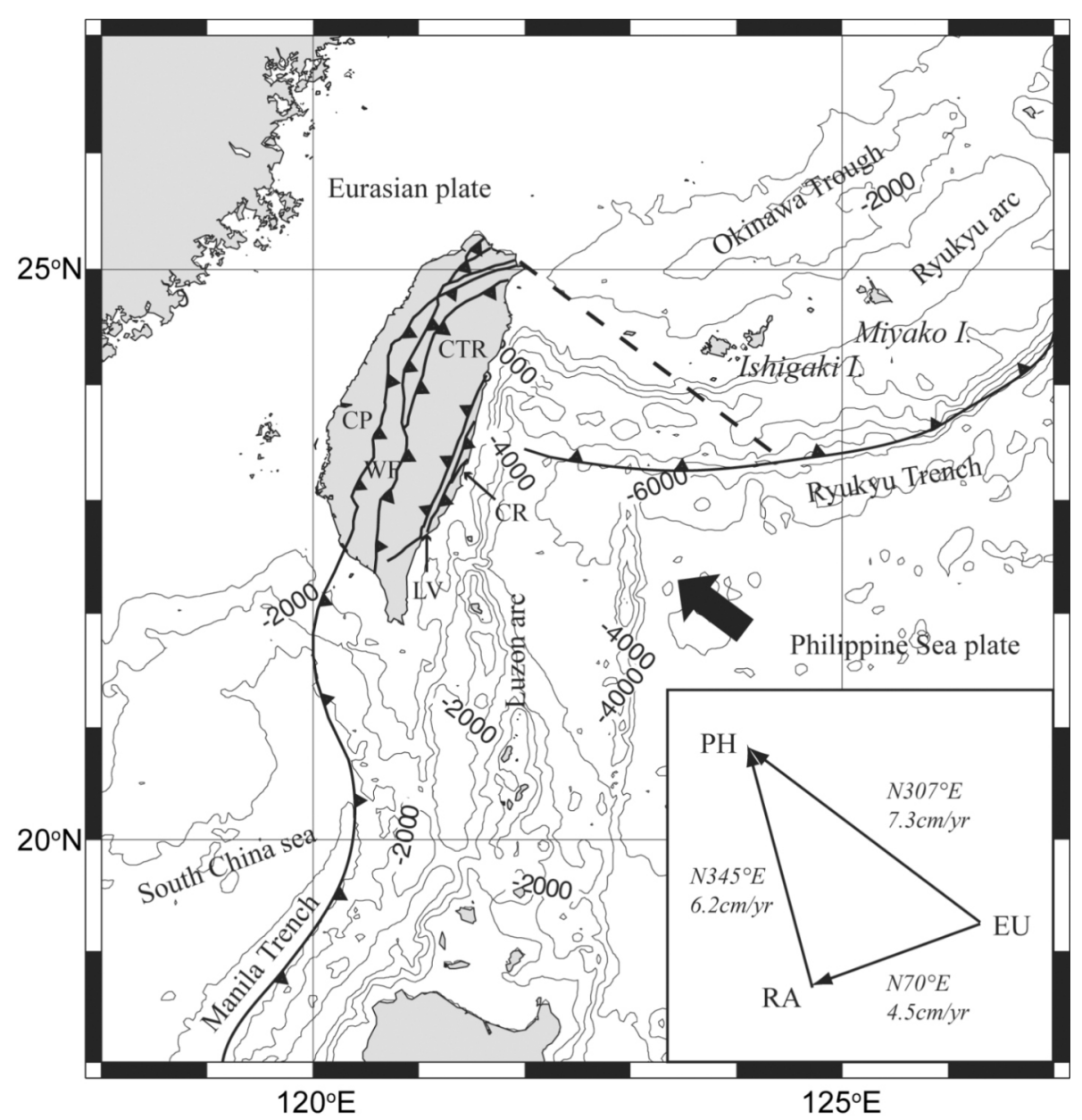

Fig. 1. Tectonic elements near Taiwan. The fold-thrust belts in western Taiwan are from Suppe (1981). The inset (right bottom) shows the velocity triangle between the Philippine Sea (PH), Eurasia (EU), and the Ryukyu forearc (RA). The Philippine Sea - Eurasian velocity is calculated from Seno et al. (1993). The Philippine Sea - Ryukyu forearc direction is based on the slip vectors of thrust-type earthquakes (Kao et al. 1998). The trend of the Ryukyu forearc is taken from that of the relict one extending to the southwest of Taiwan (Hsu and Sibuet 1995). The velocities of the Philippine Sea plate - Ryukyu forearc and Ryukyu forearc - Eurasian are determined from the triangle.

near E. Taiwan (Hsu et al. 1998), suggesting that the trench exists close to the east coast of Taiwan. This is supported by the crustal structure revealed from refraction studies offshore E. Taiwan (Hagen et al. 1988; McIntosh and Nakamura 1998; Wang et al. 2004).

To explain the location of the Ryukyu Trench near E. Taiwan, Suppe (1984) proposed that a new trench has been created behind the colliding Luzon arc, extending from the southern terminus of the Ryukyu Trench. Clift et al. (2003) proposed a similar model that the Luzon arc has been colliding to the Eurasian margin and transformed to the S. Ryukyu forearc by arc polarity reversal. However, because the southern Ryukyu forearc has been in a geotectonic situation similar to the rest of the arc since the Late Miocene (Kizaki 1986), it is doubtful that an entirely exotic arc has been accreted to this segment of the Ryukyu arc during the past several m.y. On the other hand, Lallemand et al. (2001) and Sibuet et al. (2004) tried to explain the westward propaga- tion of the trench by a tear fault, firstly along the oceancontinent boundary, and then within the continental shelf of the Eurasian plate. Teng et al. (2000) also proposed a similar tear fault within the Eurasian plate. In their models, the portion of the Ryukyu Trench west of $125^{\circ} \sim 126^{\circ} \mathrm{E}$ has been newly created by such tear faulting within the Eurasian plate. Kinematically, however, it seems difficult to shift the junction of the arc polarity reversal, i.e., the location of the tearing, southwestward, because once the overthrust/underthrust relationship between two plates is established at this type of junction, a transform fault would develop in their relative motion direction. Therefore the missing northwesttrending transform fault and the existence of the Ryukyu Trench close to E. Taiwan remain still as unsolved enigmas regarding the collision in Taiwan.

Beneath NE Taiwan, there is an intermediate-depth seismicity representing the Philippine Sea slab down to a depth about 250 - 300 km (e.g., Pezzopane and Wesnousky 1989; 
Yeh et al. 1989; Font et al. 1999; Kao and Rau 1999; Lee 2005). If the Philippine Sea plate has been subducting beneath the Eurasian plate, we expect the western edge of the subducting Philippine Sea slab to be truncated in the NW direction. The observed intermediate-depth activity is instead truncated in the NNW direction beneath NE Taiwan (Teng 1990; Font et al. 1999; Kao and Rau 1999; Teng et al. 2000).

Finally, there are significant Bouguer and Free-air gravity anomalies from E. Taiwan to the Ryukyu forearc (Hsu et al. 1998, Fig. 2). These anomalies show undulation with a wavelength of $60-80 \mathrm{~km}$, gradually diminishing to the east. The Hoping, Nanao and E. Nanao Basins in the Ryukyu forearc east of Taiwan are the morphological expression of these gravity anomalies. Because the basins have negative Bouguer anomalies, these anomalies are not simply produced by the seafloor topography or its crustal root. This feature of the gravity anomalies is not seen in the rest of the Ryukyu forearc.

In this paper, we present a new model of the collision in Taiwan, in order to resolve kinematically the enigmas stated above. The model is stimulated from the idea that the Ryukyu forearc once extended to the southwest of Taiwan (Meng 1973; Hsu and Sibuet 1995; Sibuet and Hsu 1997; Sibuet et al. 2004). Hsu and Sibuet (1995) and Sibuet and Hsu (1997) exploited the idea, using the pattern of the satellite-derived marine gravity anomalies along the continental slope. They proposed that the collision of the Luzon arc occurred with this relict Ryukyu forearc whose motion had ceased. Therefore, their model is not different from the Philippine Sea - Eurasian collision from a kinematic viewpoint. We instead hypothesize that the collision of the Luzon arc has occurred with an actively migrating Ryukyu forearc.

The plates involved in the model of the present study are the Eurasian plate, the Ryukyu forearc, and the Philippine Sea plate. Because the Luzon arc is on the Philippine Sea plate, it is part of this plate. We assume that the Ryukyu forearc has been migrating parallel to the Ryukyu Trench with respect to the Eurasian plate for the past several m.y. This might have been caused by the oblique subduction of the Philippine Sea plate as inferred from the model of slip
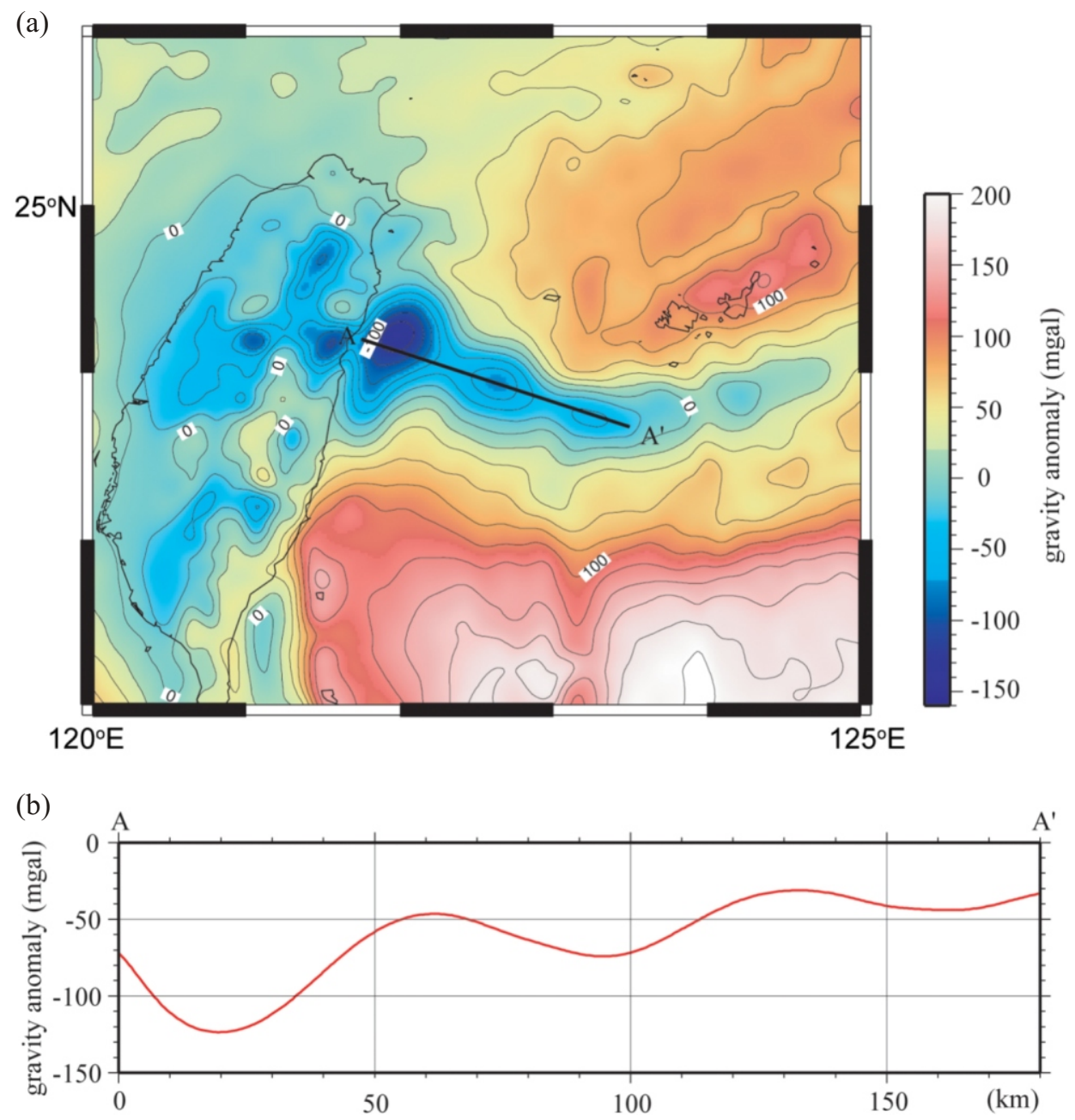

Fig. 2. (a) The Bouguer gravity anomalies near the Taiwan-S. Ryukyu region (Hsu et al. 1998). (b) The profile of the Bouguer gravity anomaly is plotted along line A-A', showing undulation with a wavelength of $60-80 \mathrm{~km}$. 
partitioning (Fitch 1972; Beck 1983; McCaffrey 1992; Platt 1993). Kuramoto and Konishi (1989) proposed an along-arc migration of the Ryukyu forearc from the stress analyses of the southern Ryukyu Islands. They cited also a fault seen offshore in reflection profiles (Boujou and Yazaki 1973), as a possible northern boundary of the Ryukyu forearc. Although Fabbri and Fournier (1999) discountenanced the lateral motion as they found only normal faults in these islands, it should be noted that the existence of such normal faults does not contradict the lateral motion proposed by Kuramoto and Konishi (1989), because if obliqueness of the Philippine Sea plate convergence beneath the S. Ryukyu forearc becomes larger to the west, we can expect a larger amount of a strikeslip component of the forearc sliver, and then its lateral stretching along the arc will result (See McCaffrey 1992). Although the boundary between the Eurasian plate and the Ryukyu forearc is not clear due to the lack of unequivocal evidence, it is likely to the south of the Ishigaki and Miyako Islands (See Fig. 1 for their locations), because recent GPS observations showed that these islands move SSE with respect to the Eurasian plate (Imanishi et al. 1996; Watanabe and Tabei 2004). We assume that it is roughly along south of these islands.

The slip vectors of thrust-type earthquakes beneath the Ryukyu forearc near Taiwan are directing $\sim \mathrm{N} 345^{\circ} \mathrm{E}$ (Kao et al. 1998), rotated by $38^{\circ}$ in a clockwise sense from the Philippine Sea - Eurasian relative motion $\left(\mathrm{N} 307^{\circ} \mathrm{E}\right)$. If they are interplate earthquakes, they may represent the slip partitioning in the southernmost Ryukyu forearc, giving another piece of evidence supporting the differential motion between the Ryukyu forearc and the Eurasian plate. We construct a velocity triangle between the Eurasian plate, the Philippine Sea plate, and the Ryukyu forearc in Fig. 1 (inset), taking the Philippine Sea - Ryukyu forearc motion as $\mathrm{N} 345^{\circ} \mathrm{E}$ from the above slip vector direction, and the strike of the Ryukyu forearc as $\mathrm{N} 70^{\circ} \mathrm{E}$, which is that of the relict Ryukyu forearc in Hsu and Sibuet (1995). In this diagram, the effect of the rifting in the Okinawa Trough is neglected, since its velocity over the past several $\mathrm{m}$.y. is in the order of $1 \mathrm{~cm} \mathrm{yr}^{-1}$ (Sibuet et al. 1998).

\section{EVOLUTION MODEL}

\subsection{Before Collision}

The Oligocene-Miocene opening of the South China Sea succeeded the Eocene rifting of the Eurasian margin (Taylor and Hayes 1983; Ru and Pigott 1986; Briais et al. 1993) and left the rifted Eurasian continental blocks in the south. They were amalgamated with the proto-Luzon arc approaching from the east (Stephan et al. 1986). Subduction of the South China Sea beneath the Luzon arc started by the early-middle Miocene as evidenced from the volcanism in the Luzon arc and has continued since then (e.g., Lallemand et al. 2001). During this period, we assume that the Luzon arc (Fig. 3a, marked by yellow lines with red triangles as volcanoes) had been moving to the Eurasian plate in the present Philippine Sea - Eurasian motion direction along a transform fault (Fig. 3a, blue line) connecting the Ryukyu and Manila Trenches. Although the motion of the Philippine Sea plate during the earlier half of this period could be directed more northerly than the present Philippine Sea - Eurasian motion (e.g., Seno and Maruyama 1984; Teng 1990), we neglect the difference at present and show first a simple kinematic evolution model of the collision in Taiwan.

We assume a simple geometry of the western boundary of the Luzon arc (the Manila Trench) as trending N-S, and the northern edge of the Luzon arc as truncated along the Philippine Sea - Eurasian motion direction (Fig. 3a). This shape of the northern edge is assumed because the convergence of the South China Sea beneath the Luzon arc occurred in this direction, and thus the volcanic arc might have been truncated in this direction at its northern end. Details of the geometry of the Luzon arc, however, do not affect the reconstruction in this study. The oblique subduction of the Philippine Sea plate from the Ryukyu Trench made the Ryukyu forearc sliver to migrate southwestward relative to the Eurasian plate. The relict Ryukyu forearc probably extended further south than Point A in Fig. 3a when the collision started if we accept the existence of the relict Ryukyu forearc in the Tainan Basin [See Sibuet and Hsu (1997)].

\subsection{Initiation of Collision}

After the collision started, the Luzon arc has collided with this southwest-moving Ryukyu forearc, not with the Eurasian continental margin (Fig. 3b). We use the velocity diagram shown in Fig. 1 to determine the geometry of the obducted and subducted parts of the Luzon arc. For this purpose, a line directing the Philippine Sea - Ryukyu forearc motion is drawn on the Luzon arc from the initial collision point at the NW corner of the Luzon arc (Fig. 3b, green line). The part west of this line has been obducted above the Ryukyu forearc-Chinese margin, because the Luzon arc south of this line is west-facing. This would have formed the accretion of the forearc material, continental slope/shelf sediments, fold and thrust belts, and uplifted accretionary wedge. In contrast, the part east of this line has been subducted beneath the Ryukyu forearc, because the Ryukyu forearc is southeast-facing. Because the obduction/subduction boundary (Fig. 3b, green line) is directing NNW, the western edge of the subducted slab is truncated in this direction.

\subsection{After Collision}

Figure $3 \mathrm{c}$ shows the geometry several m.y. after the start of the collision. The Ryukyu forearc migrates along line BA with respect to the Eurasian plate. The Luzon arc along with 


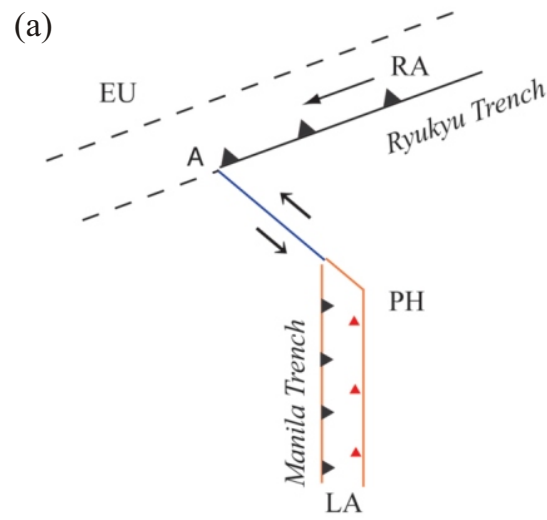

(c)

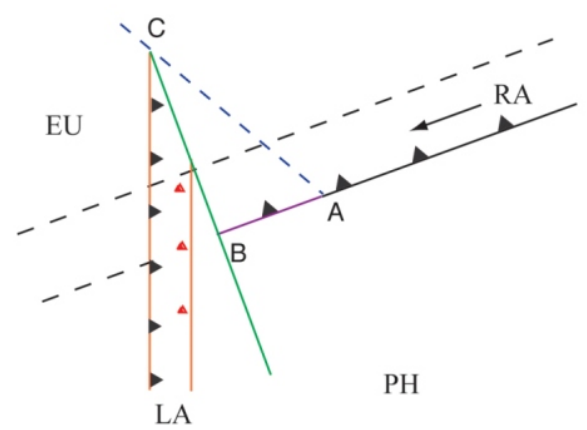

(b)

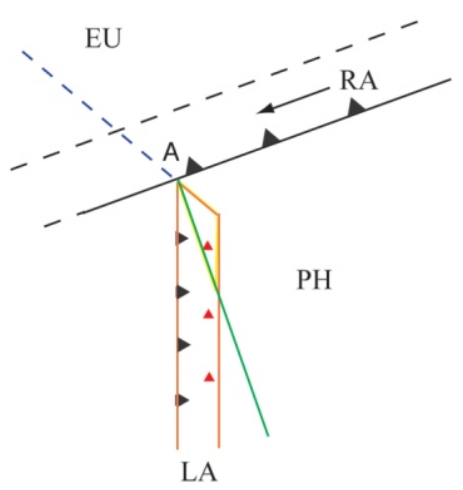

(d)

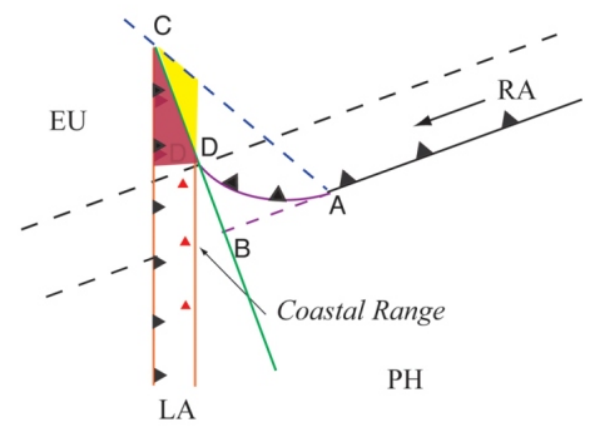

Fig. 3. Schematic representations showing the collision geometry of the Luzon arc (LA) over the Ryukyu forearc (RA) moving southwest. The Luzon arc is marked by yellow lines with red triangles showing volcanoes. (a) Before the collision: a transform fault (blue line) connecting the Ryukyu Trench and the Manila Trench was extending along the Philippine Sea - Eurasian relative motion. The Ryukyu forearc was migrating southwest with respect to the Eurasian plate due to the oblique subduction of the Philippine Sea plate. The migrating Ryukyu forearc probably existed further south than Point A. (b) Collision initiated: The Luzon arc (or the Manila Trench) started to contact the southwestward migrating Ryukyu forearc (or the Ryukyu Trench). The green line on the Luzon arc shows the Philippine Sea - Ryukyu forearc relative motion direction (see the inset of Fig. 1). The part of the Luzon arc west of this line has been obducted on the Ryukyu forearc, and that east of the line has been subducted beneath the Ryukyu forearc. (c) After the collision: The Luzon arc has been migrating NW along line CA (the Philippine Sea - Eurasian motion direction) with respect to the Eurasian plate. On the other hand, it has migrated along the direction CB (the Philippine Sea - Ryukyu forearc motion direction) with respect to the Ryukyu forearc. Because the Ryukyu forearc has migrated along line BA, lines BA, CB, and CA constitute a velocity triangle among the Ryukyu forearc, Philippine Sea plate, and Eurasian plate. (d) At present: The obducted Luzon volcanic arc corresponds to the present Coastal Range. The original trend of the Ryukyu Trench was bent to the north by the subduction of the buoyant Luzon arc. The western terminus of the Ryukyu Trench is located close to the east coast of Taiwan. The obducted and subducted parts of the Luzon arc north of the Coastal Range are colored red and yellow, respectively.

its obduction/subduction boundary migrates with respect to the Ryukyu forearc along line $\mathrm{CB}$, but along CA with respect to the Eurasian plate. Because $\mathrm{BA}, \mathrm{CB}$, and $\mathrm{CA}$ are the relative motion directions of the Ryukyu forearc - Eurasia, Luzon arc - Ryukyu forearc, and Luzon arc - Eurasia, respectively, lines BA, CB, and CA constitute the velocity triangle shown in the inset of Fig. 1. This indicates that the evolution of the collision geometry is determined by the velocity triangle, and provides us a clue to obtain information on the collision when it is compared with observed data.

Because the motion of the Luzon arc with respect to Eurasia can be decomposed into $\mathrm{CB}$ and BA components, the western end of the Ryukyu forearc migrating southwest follows the obducted Luzon arc without any vacancy. Along with this, the SW terminus of the Ryukyu Trench (Point A) migrates to Point B (Fig. 3c), and this is not a nucleation of a trench. This model then has a merit to avoid creation of a new trench since the past several m.y., which sedimentary strata around S. Ryukyu Islands do not support (Kizaki 1986). The model also puts the SW terminus of the Ryukyu Trench close to E. Taiwan (Pint B, Fig. 3c).

$\mathrm{C}$ marks the leading edge of the subducted Luzon arc. The length of the subducted slab is then measured by CB. The western edge of the subducted Luzon slab has velocities $\mathrm{BA}$ and $\mathrm{CB}$ components with respect to the Eurasian plate. The CB component is representing subduction beneath the Ryukyu forearc. The BA component would cause obstruction of the Philippine Sea slab to the South China Sea slab 
dipping southeast from E. Taiwan. This might result in tearing of the South China Sea slab, which will be discussed later.

\subsection{At Present}

Figure $3 \mathrm{c}$ is a simple evolution geometry assuming that the trend of the Ryukyu Trench has been fixed to be straight. Actually, the southern Ryukyu Trench would have been bent due to subduction of the buoyant Luzon arc or by the opening of the Okinawa Trough. This bend would have reduced the area of the subducted Luzon arc. Figure $3 \mathrm{~d}$ shows a schematic illustration taking into account this bending. The subducted part of the Luzon arc is colored yellow, and, on the other hand, the obducted part north of the western terminus of the Ryukyu Trench is colored red. The northern end of the obducted Luzon volcanic arc (the Coastal Range) is now located at the junction between the Ryukyu Trench and the obducted terrane on land. This gives us a reference point for locating the obducted Luzon arc when we apply the model to the actual geography in the next section. The subducted part (yellow) gives us an estimate of the slab length beneath NE Taiwan. The obducted part (red) formed a collision-accretion wedge and its present shape is different from that of the red area due to deformation and erosion.

\section{APPLICATION OF THE MODEL}

In this section, we apply the model proposed above to the actual geography of the Ryukyu-Taiwan region, and estimate the onset time of the collision, the amount of the obducted/subducted length of the Luzon arc, and the amount of the lateral shift of the Ryukyu forearc. We first modify the velocity diagram of Fig. 1, taking into account the rifting of the Okinawa Trough, which started around 6 Ma (Kimura 1996). We assume that, due to the rifting of the trough, in addition to the along-arc shift, the Ryukyu forearc has been moving to the Eurasian plate in the $\mathrm{N} 150^{\circ} \mathrm{E}$ direction with a velocity of $1.5 \mathrm{~cm} \mathrm{yr}^{-1}$. These are the average values for the past $6 \sim$ 7 Ma estimated by Sibuet et al. (1998). Figure 4a shows the modified velocity diagram, and can be used to reconstruct the evolution of the collision similarly to Figs. $3 \mathrm{c}$ and d.

We assume that the Manila Trench is directing N-S, and estimate the average width of the Luzon forearc to be $\sim 100 \mathrm{~km}$, which is a representative distance between the Manila Trench and the volcanic front in the region between Taiwan and Luzon (Fig. 4b). Fixing the location of the northern tip of the Coastal Range as the northern end of the obducted Luzon arc volcanic front and fixing Point A' on the axis of the Ryukyu Trench, we map the actual geography in the velocity diagram in Fig. 4a.

We color the obducted and subducted parts of the Luzon arc, north of the northern tip of the Coastal Range, red and yellow, respectively. These correspond to the areas colored in Fig. 3d. The length CD is measured to be $380 \mathrm{~km}$, which gives $270 \mathrm{~km}$ as the depth of the tip of the slab beneath NE Taiwan, if we assume a dip of $45^{\circ}$. This is similar to the maximum depth of the intermediate-depth seismicity observed beneath this region (Pezzopane and Wesnousky 1989; Yeh et al. 1989; Font et al. 1999; Kao and Rau 1999; Lee 2005). The reason why the subducted Luzon arc can give such a deep seismicity will be discussed later.

The initial contact point of the Luzon arc with the Ryukyu Trench (Point A in Fig. 4b) is located around $125^{\circ} \mathrm{E}$. The $550 \mathrm{~km}$ distance between this point and the northern tip of the obducted Luzon arc (CA in Fig. 4b), divided by the Philippine Sea - Eurasian relative velocity, gives the start time of the contact between the Manila and Ryukyu Trenches as 7.5 Ma. This is almost coincident with the start time of the collision estimated from microfossil studies (Huang et al. 1997). The time when the northern tip of the Coastal Range arrived at the Ryukyu Trench is estimated to be 4 Ma. This coincides with the start of the clockwise rotation of the Coastal Range (Lee et al. 1991) and the time of the formation of the Lichi mélange (Chi et al. 1981).

The southwestward lateral shift of the Ryukyu Trench amounts to $370 \mathrm{~km}$ (BA' in Fig. 4). This predicts that the original position of the southern terminus of the relict Ryukyu forearc, if it is located south of the Tainan Basin at present (Sibuet and Hsu 1997), was $125 \mathrm{~km}$ east of the Hengchun Peninsula of S. Taiwan at the start time of the collision. The original trend of the trench would have been gradually bent forming a cusp by the subduction of the buoyant Luzon arc (Fig. 3d). The amount of the bending is measured to be $\sim 20^{\circ}$ in Fig. $4 \mathrm{~b}$ and mostly accounts for the clockwise rotation by $25^{\circ}$ of the Ishigaki Island since $10 \mathrm{Ma}$ (Miki 1995). Miki (1995) argued that this rotation occurred between 10 and $6 \mathrm{Ma}$, by the opening of the Okinawa Trough, because Miyako Island to the east did not rotate since 6 Ma. However, Fig. 4 predicts that rotation of Miyako Island due to the bending is very small, and thus the bending since $7 \mathrm{Ma}$ is enough to explain the rotation of Ishigaki Island. We will discuss later why the buoyant subduction of the Luzon arc east of the bisecting line (yellow) was possible.

\section{DISCUSSION}

We discuss whether the proposed model of the collision is consistent with some important observational features around Taiwan; they are: the accretion wedge of the colliding Luzon arc, lateral shift of the Ryukyu forearc, intermediate-depth earthquakes beneath NE Taiwan, and the Bouguer gravity anomaly offshore E. Taiwan.

\subsection{Deformation and Erosion of the Accretion- Collision Wedge}

In this model, the accretion-collision wedge of Taiwan 
(a)

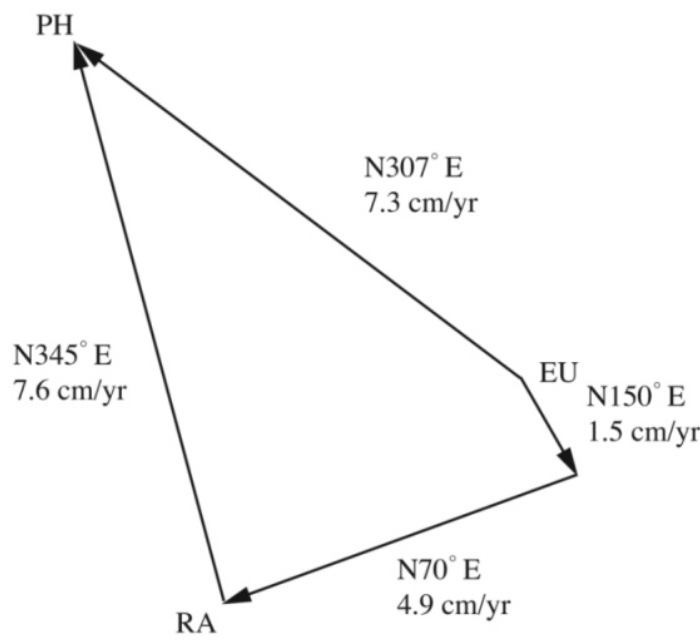

(b)

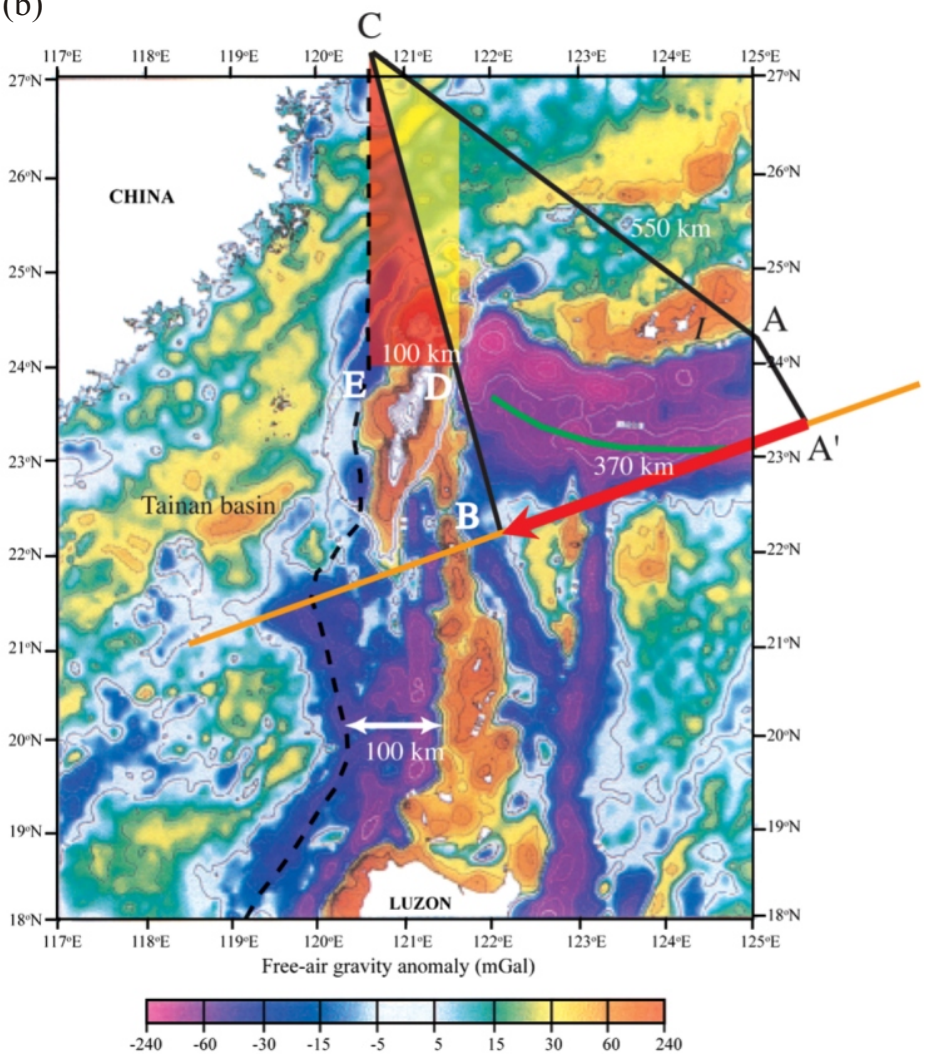

Fig. 4. (a) Velocity triangle that takes into account the rifting of the Okinawa Trough. The motion of the Ryukyu forearc (RA) to the Eurasian plate (EU) due to the rifting is assumed to be $\mathrm{N} 150^{\circ} \mathrm{E}$ direction with a velocity of $1.5 \mathrm{~cm} \mathrm{yr}^{-1}$ (Sibuet et al. 1998). The motions of the Philippine Sea plates $(\mathrm{PH})$ to other plates are the same as depicted in Fig. 1b. Application of the evolution geometry depicted in Fig. 3d to the actual geography near Taiwan, using the velocity diagram above. The free-air gravity map of Hsu et al. (1998) is used as a base map; the colors show the magnitude of the gravity anomaly. Assuming the width of the Luzon forearc to be $100 \mathrm{~km}$, the velocity triangle is mapped with the constraint that point D is the northern end of the Coastal Range, and point A' is on the Ryukyu Trench. The Ryukyu Trench has migrated from A to A' due to rifting of the Okinawa Trough, and A' to $\mathrm{B}$ due to the lateral shift.

west of the Longitudinal Valley consists of the obducted Luzon forearc and accreted Ryukyu forearc - Chinese continental margin sediments. We estimate the volume of the forearc wedge under the area shaded in red prior to the collision to be $247000 \mathrm{~km}^{3}$, assuming that (1) the dip of the subducting Eurasian plate slab is $20^{\circ}$ (Hamburger et al. 1983; Huang et al. 1997), (2) the summit of the Luzon forearc is $0 \mathrm{~m}$ above sea level, (3) the depth of the Manila Trench is $4000 \mathrm{~m}$, (4) the width of the Luzon forearc is $100 \mathrm{~km}$, and (5) the eastern edge of the obducted Luzon forearc is vertical along the bisecting line. On the other hand, we estimate the volume of the accretion-collision wedge observed at present in N. Taiwan north of line DE (Fig. 4b) and west of the Longitudinal Valley to be $169000 \mathrm{~km}^{3}$ by approximating the Central-Hsuehshan Ranges and the wedge beneath them by polygons with the bottom boundary dipping at an angle of $20^{\circ}$ (Huang et al. 1997).

Therefore a volume of more than $78000 \mathrm{~km}^{3}$ of the obducted Luzon forearc should be lost during collision. This is a minimum value because the land area of Taiwan from the
Coastal Plain to the Central Range looks to be composed of the pre-Cenozoic basement of the Chinese continental margin and Cenozoic sedimentary cover (e.g., Liou and Ernst 1984; Ho 1986). If Taiwan, and its basement west of the Longitudinal Valley, is composed of the Chinese continental material, the obducted Luzon forearc has to be totally eroded. Although this does not necessarily contradict the erosion rate $\left(\sim 5 \mathrm{~mm} \mathrm{yr}^{-1}\right)$ in the eastern Central Range (Li 1976; Willett et al. 2003), we feel that it is unlikely.

A more realistic tectonic situation would be part of the obducted Luzon forearc still remains within Taiwan west of the Longitudinal Valley, along with the Ryukyu forearc and the accreted Chinese continental margin sediments. Lundberg and Dorsey (1990) suggested a possibility that the Luzon forearc underthrusted westward at the Longitudinal Valley and was buried beneath the eastern Central Range. Another possibility we suggest is regarding the Tananao composite metamorphic terrane in the eastern Central Range as constituting the metamorphic basement of the Luzon arc. This is a paired metamorphic belt extending N-S, which was 
metamorphosed at least four times, i.e., the late Mesozoic, Paleogene, late Miocene, and Plio-Pleistocene, of which the last one is associated with the collision of the Luzon arc (Jahn et al. 1981; Liou and Ernst 1984). This terrane has been usually considered to be a metamorphic basement of the Chinese continental margin (Liou and Ernst 1984; Ho 1986; Lin and Rocker 1998). If this has been exhumed from the underthrusting Eurasian plate during the collision of the Luzon forearc, it is difficult to explain the late Miocene metamorphism, because the Eurasian margin had been a rifted passive margin since the early Tertiary [See Fig. 7 of Liou and Ernst (1984) hypothesizing westward subduction to explain this Miocene metamorphism]. We propose that the Tananao terrane has been exhumed from the obducted Luzon forearc by thickening, uplifting and erosion during the collision [See Platt (1986) for the mechanism of such exhumation]. This is a possible scenario because the Eurasian margin, which had been metamorphosed during the Mesozoic, was rifted, fragmented and had drifted owing to the South China Sea spreading, was finally incorporated into the west-facing Luzon arc (Stephan et al. 1986). This preCenozoic forearc basement would then be metamorphosed by the eastward subduction of the South China Sea during the Miocene.

An important feature of our model is that the transform fault between the Manila and Ryukyu Trenches does not need to appear, but the obducted Luzon arc is truncated in the NNW direction (Line CB). The observed collisionaccretionary prism has been extended further east beyond the bisecting line (Fig. 4b). This kind of deformation and collapse of the collision wedge has been demonstrated with experiments using plastic materials (Chemenda et al. 1997; Takada et al. 2007).

\subsection{Lateral Shift of the Ryukyu Forearc}

In our model, we assume that the Ryukyu forearc sliver has migrated southwestward relative to the Eurasian plate. The migration amounts to $370 \mathrm{~km}$ since the collision started. This might cause a serious space problem at the leading and trailing edges of the Ryukyu forearc. At the leading edge, however, the Ryukyu forearc might have been able to move along the continent-ocean boundary south of the Eurasian continent, reaching finally the southeast edge of the relict Ryukyu forearc proposed by Hsu and Sibuet (1995). At the trailing edge, at minimum, a comparable loss in forearc volume has to be accounted for somewhere in the Ryukyu arc east of Taiwan. Although there are some depressions intervening regional islands, such as the Tokara channel and the Miyako depression, it seems difficult to compensate for this deficit by such depressions only. Focal mechanisms of earthquakes show that the forearc is extended in an alongarc direction (Fournier et al. 2001; Kubo and Fukuyama 2003). The extension rate $\left(1 \times 10^{-9} \mathrm{yr}^{-1}\right)$ estimated from the sum of seismic moments produces an extension of only several meters during the past $6 \sim 7 \mathrm{Ma}$ for the $1000 \mathrm{~km}$ length of the arc.

This apparent conflict might be remedied in two ways. Although we assume that the Philippine Sea plate has been moving NW with respect to the Eurasian plate during the whole period considered, it was likely to have been moving NNW in the earlier period. Seno and Maruyama (1984) estimated that the shift from this NNW direction to the NW direction occurred sometime between 10 and $5 \mathrm{Ma}$. There are some studies suggesting that this shift occurred even later, such as at $4 \mathrm{Ma}$ (e.g., Barrier and Angelier 1986). During the period when the Philippine Sea plate was moving NNW with respect to the Eurasian plate, there was no requirement for the Ryukyu forearc to migrate laterally with respect to the Eurasian plate, in which case the amount of the missing volume at the trailing edge can be reduced by as much as $60 \%$.

Another factor that reduces this volume is that the actual trend of the Manila Trench at the northern Luzon arc might not have been NS. Obviously, the NS trend, which we assumed in Figs. 3 and 4, is too simplified. If it trended more northeasterly, apex $\mathrm{C}$ is located more southward toward $\mathrm{B}$. This will reduce the size of CAA'B in Fig. $4 \mathrm{a}$, and thus the length BA'. In this second case, the time of the initial contact between the Ryukyu forearc and the Luzon arc is also reduced by the same amount.

It should also be noted that direct evidence of the lateral shift of the Ryukyu forearc is still poor. In the southernmost Ryukyu forearc, a dextral strike-slip fault is clearly seen in the bathymetry between the accretionary prism and the backstop (Lallemand and Liu 1998; Lallemand et al. 1999). The slip partitioning of the accretionary prism was also inferred from morphological tracing of the subducted Gagua Ridge (Dominguez at al. 1998). They are, however, indications of the lateral shift between the accretionary prism and the backstop, not the whole Ryukyu forearc.

\subsection{Subduction of the Eastern Half of the Luzon Arc and Intermediate-Depth Seismicity Beneath NE Taiwan}

In this model, the eastern part of the Luzon arc has been subducting beneath the Ryukyu forearc and caused the northward bend of the southern Ryukyu arc. The reason why subduction of the eastern part of the Luzon arc was possible and collision did not occur is a problem worth considering. Kao and Rau (1999) showed that a double seismic zone exists beneath NE Taiwan. They interpreted the upper layer representing seismicity occurring in the crust of the subducted plate and/or along the plate interface, whereas the lower layer is associated with events in the uppermost slab mantle. The existence of the double seismic zone implies that, beneath NE Taiwan, dehydration from both the crust 
and the mantle occurs in the westernmost part of the subducted slab (Yamasaki and Seno 2003). Seno (2007) demonstrated that if a non-serpentinized forearc mantle wedge is laterally migrating and underthrusting at an arc-arc junction, collision happens because of a lack of lubrication due to no dehydration, and if it is serpentinized, subduction happens due to lubrication by dehydration. Because the double seismic zone observed beneath this area implies that the Luzon forearc mantle was serpentinized, it is expected that associated dehydration from this forearc would have lubricated the subduction thrust, avoiding the collision of the Luzon arc east of the bisecting line (CB).

It should also be noted that it is not possible to simply relate the age of the Philippine Sea to the depth of intermediate-depth seismicity $(\sim 270 \mathrm{~km})$. This is because the subducting part of the Philippine Sea plate is the Luzon arc, containing the basement of the Chinese continental margin (Stephan et al. 1986). If its forearc mantle contains hydrous minerals like serpentinites, it can produce the observed intermediate-depth seismicity by the dehydration embrittlement. The seismicity thus produced does not necessarily form a linear trend, but could be a plane, because the hydrous minerals can exist over an extent of the forearc mangle wedge. This is in fact seen beneath Kanto where the subducted Bonin forearc produces a plane of intermediate-depth seismicity (Seno 2007).

\subsection{Buckling of the Philippine Sea Slab}

The western edge of the subducted Philippine Sea slab has a westward component of its velocity to the Eurasian plate. This is because the NNW bisecting line is oblique to the Eurasian - Philippine Sea relative motion. The westward motion of the subducted Philippine Sea slab would thus be obstructed by the South China Sea slab (the Eurasian plate) dipping southeast from E. Taiwan. The South China Sea slab has to be torn by the Philippine Sea slab. Figure 5 shows a 3-D schematic illustration showing the torn Eurasian plate, the southwestward-moving Ryukyu forearc, and the subducting/obducting Philippine Sea plate. The tearing of the Eurasian plate was also proposed by Teng et al. (2000), Lallemand et al. (2001), and Clift et al. (2003). The merit of the present model is that the tearing is a natural result of kinematics and geometry of the subducted Philippine Sea slab.

The focal mechanisms of shallow earthquakes within the Philippine Sea plate slab beneath the southernmost Ryukyu forearc have horizontal compressional axes directing parallel to the trench axis (Pezzopane and Wesnousky 1989; Kao et al. 1998; Kao and Jian 2001), showing that the Philippine Sea slab suffers a significant E-W compressional stress. Furthermore, south of the junction of the Ryukyu forearc with Taiwan, i.e., offshore the northernmost Coastal Range, focal mechanisms of earthquakes show reverse fault-
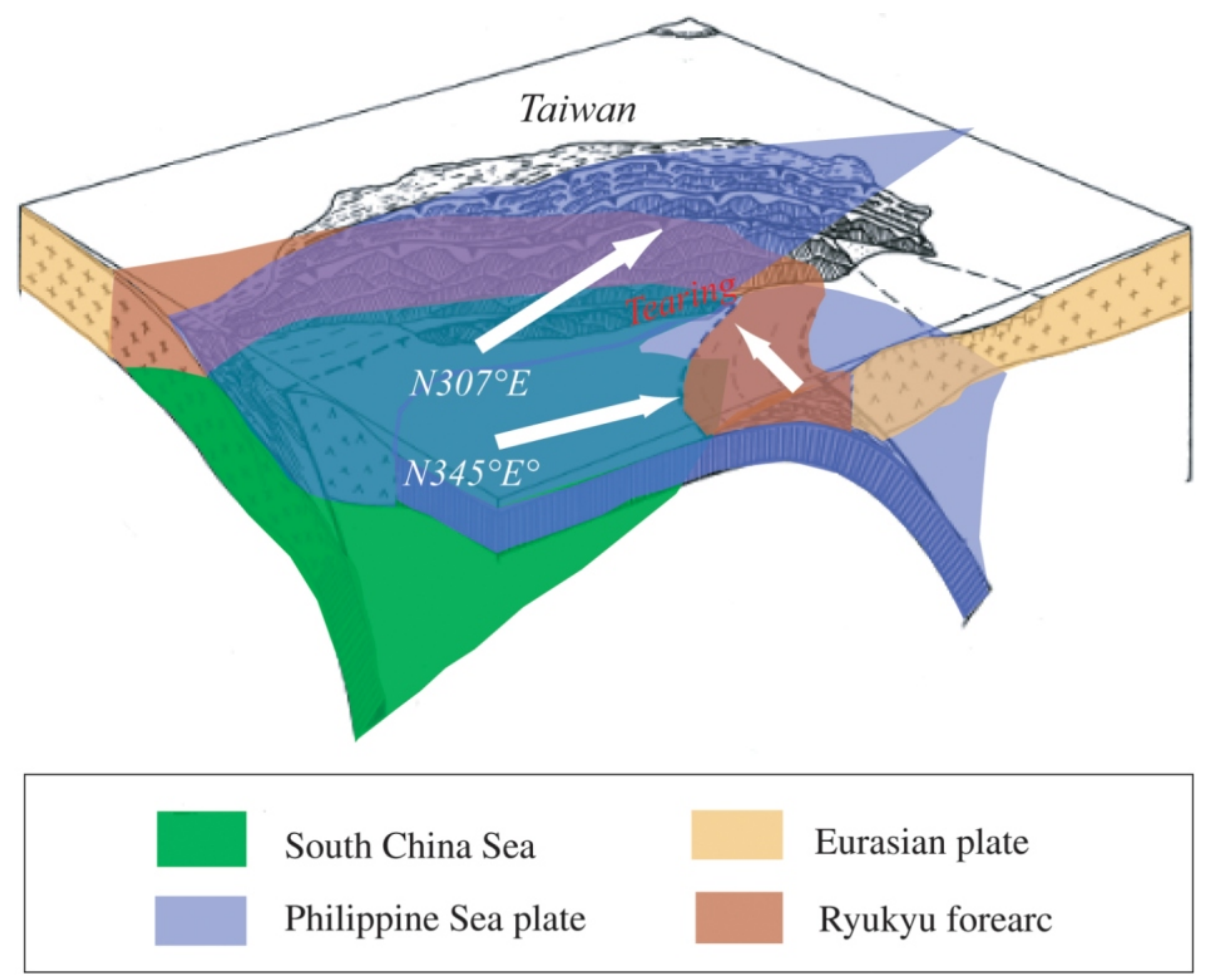

Fig. 5. 3-D view of Taiwan and the plates involved in the collision. The geometry of the Ryukyu forearc is taken from Hsu and Sibuet (1995). The Luzon arc has been moving with respect to the Ryukyu forearc in the $\mathrm{N} 348^{\circ} \mathrm{E}$ direction, and to the Eurasian plate in the N307 ${ }^{\circ} \mathrm{E}$ direction (Fig. 1 ). The difference is due to motion of the Ryukyu forearc to the Eurasian plate (See white arrows). The subducted Luzon slab has been migrating with this motion to the Eurasian plate and would tear the subducted South China Sea slab (green). 
ing in the depth range of $10-60 \mathrm{~km}$, which implies that the Philippine Sea slab might be underthrusting beneath the Eurasian plate (Wu et al. 1997). This is consistent with tearing of the Eurasian plate intervened by the Philippine Sea slab at this place.

We regard the Bouguer gravity anomaly in the Ryukyu forearc east of NE Taiwan (Fig. 2, Hsu et al. 1998) as caused by buckling of the westernmost part of the Philippine Sea slab due to this obstruction, although other factors such as uplifting due to subduction of buoyant ridges, erosion, and accretion of sediments also may modify the forearc crustal thickness (e.g., Lallemand et al. 1999). Wang et al. (2004), however, showed that the shallow portion of the subducted Philippine Sea slab is forming a cusp in the westernmost Ryukyu Trench according to seismic refraction studies, which implies that buckling of the Philippine Sea plate is at least occurring there. Folding of the subducting Philippine Sea slab at a depth range of $100-150 \mathrm{~km}$ was observed by seismicity and modeled as buckling by Chou et al. (2006), although buckling at such a large depth might not be caused by tearing.

We compute the buckling wavelength of a 2-D plate floating on a viscous substratum. We assume that the surface deflection is filled by sediments based on the refraction studies of Wang et al. (2004). The buckling wavelength $\lambda_{B}$ is then given by:

$\lambda_{\mathrm{B}}=2 \pi\left\{6 \mathrm{D} /\left[\mathrm{F}+\left(\mathrm{F}^{2}+12 \mathrm{Df}\right)^{1 / 2}\right]^{1 / 2}\right\}$

where $\mathrm{F}$ is the force applied at the ends of the plate, $\mathrm{f}$ is the restoring force due to gravity, and $\mathrm{D}$ is the flexural rigidity. $\mathrm{D}$ is defined by:

$\mathrm{D}=\mathrm{Eh}^{3} / 12\left(1-v^{2}\right)$

where $\mathrm{E}$ is the Young modulus, $\mathrm{h}$ is the effective elastic thickness, and $v$ is the Poisson's ratio. $\mathrm{f}$ is defined by:

$f=-\left(\rho_{m}-\rho_{s}\right) g$

where $\rho_{\mathrm{m}}$ is the asthenosphere density, and $\rho_{\mathrm{s}}$ is the density of sediments, and $\mathrm{g}$ is the acceleration of gravity. Using $\mathrm{E}=$ $70 \mathrm{GPa}, \mathrm{h}=15 \mathrm{~km}, v=0.25, \rho_{\mathrm{m}}=3300 \mathrm{Kg} \mathrm{m}^{-3}$, and $\rho_{\mathrm{s}}=$ $2000 \mathrm{Kg} \mathrm{m}^{-3}$, we obtain $\mathrm{F}=4 \sim 7 \times 10^{14} \mathrm{~N} \mathrm{~m}^{-1}$ for $\lambda_{\mathrm{B}}$ ranging from 60 to $80 \mathrm{~km}$. The value of $\mathrm{h}$ is taken arbitrarily to examine the amount of required stress, as discussed below, and also because it is difficult to estimate elastic thickness for the Luzon arc.

The obtained value of $\mathrm{F}$ gives horizontal compressional stress of $27 \sim 47 \mathrm{GPa}$ operating at the edges of the plate. This is unrealistically large, which implies that the elastic thickness must be much smaller than $15 \mathrm{~km}$. If we reduce the thickness by a factor of 10 , the stress will be reduced by a factor of 100. In this case, the stress becomes an order of a few hundred MPa, which might be plausible for such an anomalous place where a slab has been torn by another plate. This elastic thickness seems too small for the Tertiary age of the Philippine Sea plate. The part of the Philippine Sea plate intervening the tear is, however, the backarc of the Luzon arc (Figs. 3d and 4b) and it could be mechanically thin because of volcanism since the Miocene. Further evidence is required to support such a thin lithosphere.

\section{CONCLUSIONS}

We propose a new model of the collision in Taiwan, reappraising the idea of Hsu and Sibuet (1995) that the relict Ryukyu forearc extends to southwest of Taiwan. In our model, the Luzon arc has been colliding with the Ryukyu forearc actively migrating southwestward. The northernmost Luzon arc is divided into two parts by the NNW line along the Philippine Sea - Ryukyu forearc relative motion direction; the part west of this line has been obducted on the Ryukyu forearc, producing the collision orogen in Taiwan, and that east of it has been subducted beneath the Ryukyu forearc. The collided part has propagated NNW over the Ryukyu forearc, but northwest with respect to the Eurasian plate. The Ryukyu forearc has migrated southwestward with respect to the Eurasian plate, and follows the southwestward moving component of the obducted Luzon arc with respect to the Eurasian plate. This evolutionary model explains no existence of a transform fault striking in the Philippine Sea Eurasian motion, the proximity of the Ryukyu Trench to NE Taiwan, and the NNW striking edge of the subducted Philippine Sea slab.

Fixing the northern edge of the Coastal Range as the northern edge of the obducted volcanic front of the Luzon arc, and assuming that the width and trend of the Luzon arc are $100 \mathrm{~km}$ and N-S, respectively, the onset time of the collision, the amount of the lateral shift of the Ryukyu forearc, and the length of the subducted Philippine Sea slab are estimated to be $7.5 \mathrm{Ma}, 370$, and $380 \mathrm{~km}$, respectively. The obducted Luzon forearc wedge would have been compacted and uplifted producing the collision orogen with the accreted Chinese continental shelf/slope sediments in Taiwan. More than a volume of $\sim 78000 \mathrm{~km}^{3}$ would have been eroded from the mountain range northwest of the Coastal Range, if the obducted volume of the Luzon arc is compared with the presently observed volume. The southernmost Ryukyu Trench would have been bent to the north, rotating the Ishigaki Island by $20^{\circ}$ in a clockwise sense, by the buoyant subduction of the eastern half of the Luzon arc. This buoyant subduction, not collision, is likely to be caused by the dehydration of the subducted serpentinized forearc, as manifested by the double seismic zone in the Philippine Sea slab beneath NE Taiwan.

The model predicts that the South China Sea slab has to be torn by the Philippine Sea slab migrating westward. This 
would cause a large lateral compression of the Philippine Sea slab at its shallow western border, which might lead to the buckling of it. If undulation of the gravity anomalies at the westernmost Ryukyu forearc is caused by this buckling, the elastic thickness of the Philippine Sea plate should be small (of the order of a few $\mathrm{km}$ ) to explain the observed wavelength.

Acknowledgements We would like to thank two anonymous reviewers for critical review of the manuscript. We also thank Shu-Kun Hsu for providing us his gravity data in the digital form, Atsuki Kubo for discussion, and Youichiro Takada and J. C. Sibuet for providing their papers. Some of the maps and figures have been prepared using the Generic Mapping Tools (GMT) software (Wessel and Smith, EOS, Trans. AGU, 76, 329, 1995).

\section{REFERENCES}

Barrier, E. and J. Angelier, 1986: Active collision in eastern Taiwan: The Coastal Range. Tectonophysics, 125, 39-72, doi: 10.1016/0040-1951(86)90006-5. [Link]

Beck, Jr., M. E., 1983: On the mechanism of tectonic transport in zones of oblique subduction. Tectonophysics, 93, 1-11, doi: 10.1016/0040-1951(83)90230-5. [Link]

Boujou, T. and K. Yazaki, 1973: Cenozoic formations in southern part of the Ryukyu arc and the significance of the Ryukyu Tectonic Line. Bull. Geol. Surv. Jpn, 24, 107-108. (in Japanese)

Briais, A., P. Patriat, and P. Tapponnier, 1993: Updated interpretation of magnetic anomalies and seafloor spreading stages in the South China Sea: Implications for the Tertiary tectonics of Southeast Asia. J. Geophys. Res., 98, 62996328, doi: 10.1029/92JB02280. [Link]

Chemenda, A. I., R. K. Yang, C. H. Hsieh, and A. L. Groholsky, 1997: Evolutionary model for the Taiwan collision based on physical modelling. Tectonophysics, 274, 253-274, doi: 10.1016/S0040-1951(97)00025-5. [Link]

Chi, W. R., J. Namson, and J. Suppe, 1981: Stratigraphic record of plate interactions in the Coastal Range of eastern Taiwan. Mem. Geol. Soc. China, 4, 155-194.

Chou, H. C., B. Y. Kuo, S. H. Hung, L. Y. Chiao, D. Zhao, and Y. M. Wu, 2006: The Taiwan-Ryukyu subduction-collision complex: Folding of a viscoelastic slab and the double seismic zone. J. Geophys. Res., 111, B04410, doi: 10.1029/ 2005JB003822. [Link]

Clift, P. D., H. Shouten, and A. E. Draut, 2003: A general model of arc-continent collision and subduction polarity reversal from Taiwan and the Irish Caledonides. In: Larter, R. D. and P. T. Leat (Eds.), Intra-Oceanic Subduction Systems: Tectonic and Magmatic Processes. Geol. Soc., London, Spec. Pub., 219, 81-98.

Dominguez, S., S. Lallemand, J. Malavieille, and P. Schnürle, 1998: Oblique subduction of the Gagua Ridge beneath the Ryukyu accretionary wedge system: Insights from marine observations and sandbox experiments. Mar. Geophys. Res., 20, 383-402, doi: 10.1023/A:1004614506345. [Link]

Fabbri, O. and M. Fournier, 1999: Extension in the southern Ryukyu arc (Japan): Link with oblique subduction and back arc rifting. Tectonics, 18, 486-497, doi: 10.1029/ 1999TC900001. [Link]

Fitch, T. J., 1972: Plate convergence, transcurrent faults, and internal deformation adjacent to southeast Asia and the western Pacific. J. Geophys. Res., 77, 4432-4460, doi: 10.1029/JB077i023p04432. [Link]

Font, Y., S. Lallemand, and J. Angelier, 1999: Transition between the active origin of Taiwan and the Ryukyu subduction: New insight from seismicity. Bull. Soc. Géol. Fr., 170, 271-283.

Fournier, M., O. Fabbri, J. Angelier, and J. P. Cadet, 2001: Regional seismicity and on-land deformation in the Ryukyu arc: Implications for the kinematics of opening of the Okinawa Trough. J. Geophys. Res., 106, 13751-13768, doi: 10.1029/2001JB900010. [Link]

Hagen, R. A., F. K. Duennebier, and V. Hsu, 1988: A seismic refraction study of the crustal structure in the active seismic zone east of Taiwan. J. Geophys. Res., 93, 4785-4796, doi: 10.1029/JB093iB05p04785. [Link]

Hall, R., 2002: Cenozoic geological and plate tectonic evolution of SE Asia and the SW Pacific: Computer-based reconstructions, model and animations. J. Asian Earth Sci., 20, 353-431, doi: 10.1016/S1367-9120(01)00069-4. [Link]

Hamburger, M. W., R. K. Cardwell, and B. Isacks, 1983: Seismotectonics of the northern Philippine island arc. In: Hayes, D. E. (Ed.), The Tectonic and Geologic Evolution of Southeast Asian Seas and Islands, Part 2, Geophys. Monogr., AGU, Washington DC, 27, 1-22.

Ho, C. S., 1986: A synthesis of the geologic evolution of Taiwan. Tectonophysics, 125, 1-16, doi: 10.1016/0040-1951 (86)90004-1. [Link]

Hsu, S. K. and J. C. Sibuet, 1995: Is Taiwan the result of arccontinent or arc-arc collision? Earth Planet. Sci. Lett., 136, 315-324, doi: 10.1016/0012-821X(95)00190-N. [Link]

Hsu, S. K., C. S. Liu, C. T. Shyu, S. Y. Liu, J. C. Sibuet, S. Lallemand, C. Wang, and D. Reed, 1998: New gravity and magnetic anomaly maps in the Taiwan-Luzon region and their preliminary interpretation. Terr. Atmos. Ocean. Sci., 9, 509-532.

Huang, C. Y., C. T. Shyu, S. B. Lin, T. Q. Lee, and D. D. Sheu, 1992: Marine geology in the arc-continent collision zone off southeastern Taiwan: Implications for late Neogene evolution of the Coastal Range. Mar. Geol., 107, 183-212, doi: 10.1016/0025-3227(92)90167-G. [Link]

Huang, C. Y., W. Y. Wu, C. P. Chang, S. Tsao, P. B. Yuan, C. W. Lin, and K. Y. Xia, 1997: Tectonic evolution of accretionary prism in the arc-continent collision terrane of Taiwan. Tectonophysics, 281, 31-51, doi: 10.1016/S00401951(97)00157-1. [Link]

Imanishi, M., F. Kimata, N. Inamori, R. Miyajima, T. Okuda, K. Takai, and K. Hirahara, 1996: Horizontal displacements by 
GPS measurements at the Okinawa-Sakishima Islands (1994-1995). Jisin, 49, 417-421. (in Japanese)

Jahn, B. M., J. G. Liou, and H. Nagasawa, 1981: High-pressure metamorphic rocks of Taiwan: REE geochemistry, $\mathrm{Rb}-\mathrm{Sr}$ ages and tectonic implications. Mem. Geol. Soc. China, 4, 497-520.

Kao, H. and R. J. Rau, 1999: Detailed structures of the subducted Philippine Sea plate beneath northeast Taiwan: A new type of double seismic zone. J. Geophys. Res., 104, 1015-1033, doi: 10.1029/1998JB900010. [Link]

Kao, H. and P. R. Jian, 2001: Seismogenic patterns in the Taiwan region: Insights from source parameter inversion of BATS data. Tectonophysics, 333, 179-198, doi: 10.1016/ S0040-1951(00)00274-2. [Link]

Kao, H., S. J. Shen, and K. F. Ma, 1998: Transition from oblique subduction to collision: Earthquakes in the southernmost Ryukyu arc-Taiwan region. J. Geophys. Res., 103, 72117229, doi: 10.1029/97JB03510. [Link]

Kimura, M., 1996: Active rift system in the Okinawa Trough and its northeastern continuation. Bull. Disas. Prev. Res. Inst., Kyoto Univ., 45, 27-38.

Kizaki, K., 1986: Geology and tectonics of the Ryukyu Islands. Tectonophysics, 125, 193-207, doi: 10.1016/0040-1951 (86)90014-4. [Link]

Kubo, A. and E. Fukuyama, 2003: Stress field along the Ryukyu arc and the Okinawa trough inferred from moment tensors of shallow earthquakes. Earth Planet. Sci. Lett., 210, 305316, doi: 10.1016/S0012-821X(03)00132-8. [Link]

Kuramoto, S. and K. Konishi, 1989: The Southwest Ryukyu Arc is a migrating microplate (forearc sliver). Tectonophysics, 163, 75-91, doi: 10.1016/0040-1951(89)90119-4. [Link]

Lallemand, S. and C. S. Liu, 1998: Geodynamic implications of present-day kinematics in the southern Ryukyus. J. Geol. Soc. China, 41, 551-564.

Lallemand, S., C. S. Liu, S. Dominguez, P. Schnürle, J. Malavieille, and the ACT scientific crew, 1999: Trench-parallel stretching and folding of forearc basins and lateral migration of the accretionary wedge in the southern Ryukyus: A case of strain partition cased by oblique convergence. Tectonics, 18, 231-247, doi: 10.1029/1998TC900011. [Link]

Lallemand, S., Y. Font, H. Bijwaard, and H. Kao, 2001: New insights on 3-D plates interaction near Taiwan from tomography and tectonic implications. Tectonophysics, 335, 229-253, doi: 10.1016/S0040-1951(01)00071-3. [Link]

Lee, C. S., 2005: Using the OBS and the marine cable connected OBS to study the seismogenic zones between Taiwan and the Ryukyu. Proc. Inter. Symp. Marine Geosciences, JAMSTEC, Yokohama, 67-68.

Lee, T. Q., C. Kissel, E. Barrier, C. Laj, and W. R. Chi, 1991: Paleomagnetic evidence for a diachronic clockwise rotation of the Coastal Range, eastern Taiwan. Earth Planet. Sci. Lett., 104, 245-257, doi: 10.1016/0012-821X(91) 90207-X. [Link]

Li, Y. H., 1976: Denudation of Taiwan Island since the Pliocene epoch. Geology, 4, 105-107, doi: 10.1130/0091-7613 $(1976) 4<105$ :DOTIST $>2.0 . C O ; 2$. [Link]

Lin, C. H. and S. W. Roecker, 1998: Active crustal subduction and exhumation in Taiwan. In: Hacker, B. R. and J. G. Liou (Eds.), When Continents Collide: Geodynamics and Geochemistry of Ultra High-Pressure Rocks, Kluwer Academic Publishers, 1-25.

Liou, J. G. and W. G. Ernst, 1984: Summary of Phanerozoic metamorphism in Taiwan. Mem. Geol. Soc. China, 6, 133152.

Liu, C. S., I. L. Huang, and L. S. Teng, 1997: Structural features off southwestern Taiwan. Mar. Geol., 137, 305-319, doi: 10.1016/S0025-3227(96)00093-X. [Link]

Lundberg, N. and R. J. Dorsey, 1990: Rapid Quaternary emergence, uplift, and denudation of the Coastal Range, eastern Taiwan. Geology, 18, 638-641, doi: 10.1130/0091-7613 (1990)018<0638:RQEUAD>2.3.CO;2. [Link]

Lundberg, N., D. L. Reed, C. S. Liu, and J. Leiske, Jr., 1997: Forearc-basin closure and arc accretion in the submarine suture zone south of Taiwan. Tectonophysics, 274, 5-23, doi: 10.1016/S0040-1951(96)00295-8. [Link]

Malavieille, J., S. E. Lallemand, S. Dominguez, A. Deschamps, C. Y. Lu, C. S. Liu, and P. Schnürle, 2002: Arc-continent collision in Taiwan: New marine observations and tectonic evolution. Geo. Soc. Am. Spec. Pap., 358, 187-211.

McCaffrey, R., 1992: Oblique plate convergence, slip vectors, and forearc deformation. J. Geophys. Res., 97, 8905-8915, doi: 10.1029/92JB00483. [Link]

McIntosh, K. and Y. Nakamura, 1998: Crustal structure beneath the Nanao forearc basin from TAICRUST MCS/OBS Line 14. Terr. Atmos. Ocean. Sci., 9, 345-362.

Meng, C. Y., 1973: The structural relation of the island of Taiwan with the Ryukyu island arc. In: The Western Pacific, Island Arc, Marginal Seas, Geochemistry, 275-286.

Miki, M., 1995: Two-phase opening model for the Okinawa Trough inferred from paleomagnetic study of the Ryukyu arc. J. Geophys. Res., 100, 8169-8184, doi: 10.1029/ 95JB00034. [Link]

Pezzopane, S. K. and S. G. Wesnousky, 1989: Large earthquakes and crustal deformation near Taiwan. J. Geophys. Res., 94, 7250-7264, doi: 10.1029/JB094iB06p07250. [Link]

Platt, J. P., 1986: Dynamics of orogenic wedges and the uplift of high-pressure metamorphic rocks. Geol. Soc. Am. Bull., 97, 1037-1053, doi: 10.1130/0016-7606(1986)97<1037: DOOWAT $>2.0 . \mathrm{CO} ; 2$. [Link]

Platt, J. P., 1993: Mechanics of oblique convergence. J. Geophys. Res., 98, 16239-16256, doi: 10.1029/93JB00888. [Link]

$\mathrm{Ru}, \mathrm{K}$. and J. D. Pigott, 1986: Episodic rifting and subsidence in the South China Sea. AAPG Bull., 70, 1136-1155.

Seno, T., 2007: Collision versus subduction: From the viewpoint of slab dehydration. In: Dixon, T. and C. Moore (Eds.), The Seismogenic Zone of Subduction Thrust Faults, Columbia Univ. Press, 601-623. 
Seno, T. and S. Maruyama, 1984: Paleogeographic reconstruction and origin of the Philippine Sea. Tectonophysics, 102, 53-84, doi: 10.1016/0040-1951(84)90008-8. [Link]

Seno. T., S. Stein, and A. E. Gripp, 1993: A model for the motion of the Philippine Sea plate consistent with NUVEL-1 and geological data. J. Geophys. Res., 98, 17941-17948, doi: 10.1029/93JB00782. [Link]

Sibuet, J. C. and S. K. Hsu, 1997: Geodynamics of the Taiwan arc-arc collision. Tectonophysics, 274, 221-251, doi: 10.1016/S0040-1951(96)00305-8.[Link]

Sibuet, J. C., B. Deffontaines, S. K. Hsu, N. Thareau, J. P. Le Formal, C. S. Liu, and ACT party, 1998: Okinawa Trough rough backarc basin: Early tectonic and magmatic evolution. J. Geophys. Res., 103, 30245-30267, doi: 10.1029/ 98JB01823. [Link]

Sibuet, J. C., S. K. Hsu, and E. Debayle, 2004: Geodynamic context of the Taiwan orogen. In: Continent-Ocean Interactions Within East Asian Marginal Seas. Geophys. Monogr., 149, AGU, Washington, DC, 127-158.

Stephan, J. F., R. Blanchet, C. Rangin, B. Pelletier, J. Letouzey, and C. Muller, 1986: Geodynamic evolution of the Taiwan-Luzon-Mindoro belt since the late eocene. Tectonophysics, 125, 245-268, doi: 10.1016/0040-1951(86) 90017-X. [Link]

Suppe, J., 1981: Mechanics of mountain building and metamorphism in Taiwan. Mem. Geol. Soc. China, 4, 67-89.

Suppe, J., 1984: Kinematics of arc-continent collision, flipping of subduction, and back-arc spreading near Taiwan. Mem. Geol. Soc. China, 6, 21-33.

Takada, Y., Y. Fukahata, A. Hashima, T. Terakawa, K. Fukui, T. Yanagisawa, Y. Ikeda, G. Kimura, and M. Matsu'ura, 2007: Development of three-dimensional basement structure in Taiwan deduced from past plate motion: Consistency with the present seismicity. Tectonics, 26, TC3004, doi: 10.1029/2006TC001957. [Link]

Taylor, B. and D. E. Hayes, 1983: Origin and history of the South China Sea Basin. In: Hayes, D. E. (Ed.), The Tectonic and Geologic Evolution of Southeast Asian Seas and Islands. Geophys. Monogr., 23, AGU, Washington, DC, 23-56.

Teng, L. S., 1990: Geotectonic evolution of late Cenozoic arccontinent collision in Taiwan. Tectonophysics, 183, 57-76, doi: 10.1016/0040-1951(90)90188-E. [Link]

Teng, L. S., C. T. Lee, Y. B. Tsai, and L. Y. Hsiao, 2000: Slab breakoff as a mechanism for flipping of subduction polarity. Geology, 28, 155-158, doi: 10.1130/0091-7613(2000) 28<155:SBAAMF $>2.0 . C O ; 2$. [Link]

Wang, T. K., S. F. Lin, C. S. Liu, and C. S. Wang, 2004: Crustal structure of the southernmost Ryukyu subduction zone: OBS, MCS and gravity modelling. Geophys. J. Int., 157, 147-163, doi: 10.1111/j.1365-246X.2004.02147.x. [Link]

Watanabe, T. and T. Tabei, 2004: GPS velocity field and seismotectonics of the Ryukyu arc, southwest Japan. Jisin, 57, 1-10. (in Japanese)

Willett, S. D., D. Fisher, C. Fuller, E. C. Yeh, and C. Y. Lu , 2003: Erosion rates and orogenic-wedge kinematics in Taiwan inferred from fission-track thermochronometry. Geology, 31, 945-948, doi: 10.1130/G19702.1. [Link]

Wu, F. T., R. J. Rau, and D. Salzberg, 1997: Taiwan orogeny: Thin-skinned or lithospheric collision. Tectonophysics, 274, 191-220, doi: 10.1016/S0040-1951(96)00304-6. [Link]

Yamasaki, T. and T. Seno, 2003: Double seismic zones and dehydration embrittlement of the subducting slab. J. Geophys. Res., 108, 2212, doi: 10.1029/2002JB001918. [Link]

Yeh, Y. H., C. H. Lin, and S. W. Roecker, 1989: A study of upper crustal structures beneath northeastern Taiwan: Possible evidence of the western extension of Okinawa Trough. Proc. Geol. Soc. China, 32, 139-156. 